\title{
Large deletion causing von Hippel-Lindau disease and hereditary breast cancer syndrome
}

\author{
Karol Krzystolik ${ }^{1,2^{*}}$, Anna Jakubowska ${ }^{2}$, Jacek Gronwald ${ }^{2}$, Maciej R Krawczyński ${ }^{3}$, Monika Drobek-Słowik', \\ Leszek Sagan ${ }^{4}$, Leszek Cyryłowski ${ }^{5}$, Wojciech Lubiński ${ }^{1}$, Jan Lubiński ${ }^{2}$ and Cezary Cybulski ${ }^{2}$
}

\begin{abstract}
Patients with intragenic mutations of the VHL gene have a typical disease presentation. However in cases of large VHL gene deletions which involve other genes in the proximity of the VHL gene a presentation of the disease can be different.

To investigate whether large VHL deletions that remove the FANCD2 gene have an effect on the disease phenotype, we studied a family with a $50 \mathrm{~kb}$ large deletion encompassing these two genes. Four patients in this family were affected by VHL-related lesions. However one carrier of the deletion also had bilateral ductal breast cancer at age 46 and 49. Both tumors were of $\sim 2 \mathrm{~cm}$ in diameter. On one side lymph nodes were affected. One tumor was ER- and PR-negative (HER2 s unknown) and the second was ER- and PR-positive, and HER2-negative.

Our study suggests that a deletion of FANCD2 gene, an important gene in the DNA repair pathway, may be associated with an increased risk of breast cancer, but further studies are needed in this regard.
\end{abstract}

\section{Introduction}

Von Hippel-Lindau (VHL) disease is a rare autosomal dominant disorder characterized by a predisposition to haemangioblastomas of the central nervous system (cHAB) and retina (rHAB), renal cell carcinomas (RCC), pheochromocytomas and paragangliomas, endolymphatic sac tumors (ELST), pancreatic neuroendocrine tumors (PNET), papillary cystadenomas of epididymis, and adnexal papillary tumors of probable mesonephric origin (APMO) [1-3]. The disease is caused by germline mutations in the VHL tumor suppressor gene on a short arm of chromosome 3. In most cases, VHL disease is caused by single base substitutions, microdeletions or microinsertions, however approximately $30 \%$ of VHL patients carry a deletion of a part or of the entire $V H L$ gene [4-6].

Patients with small intragenic mutations of the $V H L$ gene have a typical disease presentation. However this may not be the truth in cases of carriers of large deletions. Large deletions may involve other genes in the proximity of the

\footnotetext{
*Correspondence: krzystolikk@poczta.onet.pl

'Department of Ophthalmology, Pomeranian Medical University (PUM), Szczecin, Poland

${ }^{2}$ International Hereditary Cancer Center, Department of Genetics, Pathology PUM, Szczecin, Poland

Full list of author information is available at the end of the article
}

VHL gene, i.e. FANCD2, C3orf10, CNTN6, IRAK2, GHRL or MLH1 genes that may have an effect on the disease presentation. For example, there is some evidence to suggest that large deletions of $V H L$ and of C3orf10 are associated with lower life time risk of kidney cancer compared to the deletions which do not include the C3orf10 gene [7-10]. However, the impact of the extent of large deletions encompassing $V H L$ and other adjacent genes on phenotype has not been extensively studied. In particular, it was not investigated whether large $V H L$ deletions that include the FANCD2 gene - an important gene in the DNA damage repair signaling pathway, have an effect on disease phenotype.

\section{Material and methods \\ Patients}

We studied a phenotype of a family with a large deletion of the VHL gene that involves the FANCD2 gene. This family included 11 family members (Figure 1), 4 patients had VHL-related tumors, and 2 patients had other tumors (breast cancer, prostate cancer) (Table 1). Blood samples were available from 3 family members (a 53 year old woman with bilateral breast cancer and VHL disease, her 31 year old son with VHL disease and her healthy 30 year old daughter). 


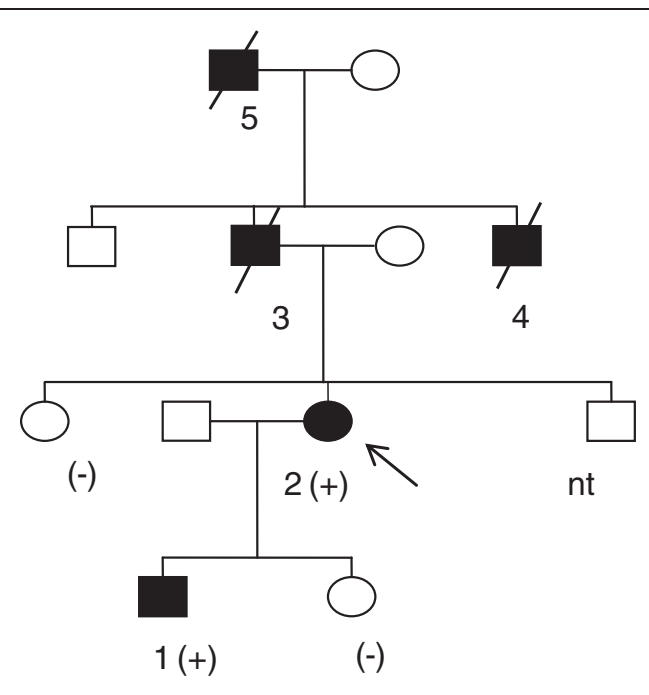

(+) Del Ex $1 \mathrm{vhl}+$ C3ORF10

$(-)$ nodel

nt - not tested

Figure 1 Pedegree of the affected family.

\section{Mutation analysis}

DNA was extracted from whole blood using standard techniques. Peripheral blood leukocytes obtained from the patient were processed for DNA isolation using standard methods. The entire coding region of $V H L$ gene was sequenced using direct Sanger sequencing as described previously [6]. Large genomic rearrangements were detected using MLPA analysis using the SALSA MLPA kit P016 VHL assay (MRC Holland, Amsterdam, The Netherlands). This assay includes 17 probes from distal chromosome 3p25 (from telomere to centromere): one probe for CNTN6, two probes for $F A N C D 2$, two probes for C3ORF10, four probes for $V H L$

Table 1 VHL related and non-VHL related lesions detected in the affected family

\begin{tabular}{llll}
\hline $\begin{array}{l}\text { Patient } \\
\text { no. }\end{array}$ & $\begin{array}{l}\text { VHL related CNS } \\
\text { lesions }\end{array}$ & $\begin{array}{l}\text { VHL related } \\
\text { visceral lesions }\end{array}$ & $\begin{array}{l}\text { Non VHL related } \\
\text { tumors }\end{array}$ \\
\hline 1 & $\begin{array}{l}\text { HbCb age 18, Hbs } \\
\text { age 19,Hbs age } 31\end{array}$ & Renal cysts & \\
2 & HbCb -age 54 & RCC age 54 & BrCa - age 46 \\
3 & HbCb 65 & NA & BrCa - age 49 \\
4 & $\mathrm{NA}$ & $\mathrm{NA}$ & $\mathrm{Pr}-$ age 65 \\
5 & $\mathrm{HbCb} 69$ & $\mathrm{NA}$ & \\
\hline
\end{tabular}

$\mathrm{RCC}$ renal cell carcinoma, $\mathrm{BrCa}$ - breast carcinoma, $\mathrm{HbCb}$ - heamangioblastoma of cerebellum, $\mathrm{Hbs}$ - spinal haemangioblastoma, $\mathrm{Pr}$ - prostate cancer, NA- no examination, no imaging studies. exon 1, three probes for $V H L$ exon 2, two probes for $V H L$ exon 3, IRAK2 probe, GHR probe, and $M L H 1$ probe. The products of MLPA reactions were analyzed with automated sequencer (model 373A, ABI, USA).

\section{Results}

In two patients with VHL disease, a large germline deletion involving the exon 1 of the $V H L$ gene, the C3ORF10 gene and a fragment of the FANCD2 gene was detected. The presence of the deletion was confirmed using MLPA in repeated analyses using DNA samples isolated from two different blood samples for each patient. In brief, in MLPA, the peak height was significantly lower for the six probes (three probes for $V H L$ exon 1, two probes for C3ORF10 and 1 probe for $F A N C D 2$ gene) indicating the presence of a heterozygous deletion. Based of the localization of these six probes, we estimate that the length of this deletion is approximately $50 \mathrm{~kb}$ (between $43 \mathrm{~kb}$ to $54 \mathrm{~kb}$ ). The telomeric breakpoint lies within the FANCD2 gene between exon 35 and exon 43 of the FANCD2 gene (a signal for the probe specific for exon 43 of the FANCD2 gene was abnormal, and signal for the probe for exon 35 of the FANCD2 gene was appropriate). The centromeric breakpoint is located in intron 1 the $V H L$ gene.

The clinical presentation of the VHL disease in this family includes CNS heamangioblastoma seen in four patients, kidney cancer diagnosed in one patient and no retina heamangioblastoma or pheochromocytoma. Age of diagnosis and localization of these typical VHL-associated lesions are shown in Table 1.

Interestingly, one carrier of the deletion developed bilateral breast cancer at age 46 and 49. First cancer was diagnosed at the age of 46 in her right breast. The patient was treated by mastectomy with postoperative chemotherapy (CMF). Histopathological examination revealed invasive ductal breast carcinoma of $1.8 \mathrm{~cm}$ size. The tumor was ER- negative, and PR-negative (HER2 was not analyzed). A metastasis in 1 axillary lymph node was found. There was no evidence of distant metastases. The tumor was classified as T1c pN1a M0, stage IIA; grade G2. Three years later, at the age of 49, she was diagnosed with cancer of her left breast. It was an invasive ductal carcinoma of $2.0 \mathrm{~cm}$ size. The tumor was ERpositive, PR-positive, and HER2-negative. There was no evidence for lymph-node or distant metastases. The tumor was classified as T1c pN 0 M0, stage IA, grade G2 and treated with mastectomy and tamoxifen. Ki67 expression was not tested. At present, 9 and 6 years after treatment of the breast cancers there is no evidence of breast cancer recurrence. However at age of 54, lesions typical for VHL disease including cerebellar haemangioblastoma and renal cell carcinoma were diagnosed in the patient. 
There was also a history of prostate cancer in one affected male family member at the age of 65 years although his DNA sample was not available for MLPA analysis.

\section{Discussion}

To our knowledge this is the first study to suggest an association between a large deletion involving the FANCD2 gene and bilateral breast cancer. FANCD2 is one of eight genes known to cause the autosomal recessive disorder Fanconi anaemia (FA), which is characterized by spontaneous chromosomal instability, immunodeficiency, and a predisposition to cancer [11-14]. FANCD2 plays an important role in the recombination DNA repair pathways [15]. The activated FANCD2 protein co-localises with other DNA repair proteins such as $B R C A 1, B R C A 2, A T M, N B S 1$ and RAD51 [16]. It has been suggested that FANCD2 and BRCA1 interact directly in this process [11]. In response to ionising radiation, FANCD2 is also phosphorylated by ATM, which leads to the activation of an S-phase checkpoint of the cell cycle [16]. Therefore, FANCD2 is good candidate for breast cancer susceptibility gene.

It is interesting that biallelic mutations of $B R C A 2$, the major gene for hereditary breast cancer, were also shown to cause Fanconi anemia. However, it has been reported that FA gene mutations, other than in BRCA2, are unlikely to be a frequent cause of highly penetrant breast cancer predisposition. Analysis of the FA genes (FANCA, $B, C, D 1, D 2, E, F, G)$ in 88 non-BRCA1, non-BRCA2 breast cancer families failed to identify any highly penetrant mutations for breast cancer [17]. In another study, 399 women, from 356 non-BRCA1/2 breast cancer families (some had more than one index case because multiple women were affected at the same age), were screened for FANCD2 mutations by DHPLC/sequencing and no pathogenic mutations were identified [18].

In our study, breast cancers seen in carrier of a deletion of FANCD2 gene were invasive, grade 2 ductal carcinomas. Both were tumors of $\sim 2 \mathrm{~cm}$ in diameter. One of these had lymph node metastases. One tumor was ER- and PR-negative (HER2 status unknown) and the other was ER- and PR-positive, but HER2-negative. This may suggest that a mutation in $F A N C D 2$ predispose to invasive breast cancer of ductal type, however further studies are needed in this regard.

Given that both FANCD2 and BRCA2 mutations (in homozygous state) cause the same chromosomal instability syndrome called Fanconi anemia, it is likely that breast cancers that arise in carriers of a mutation in these genes may have similar clinical characteristics. In this context it is important to mention that BRCA2associated breast cancers exhibit higher grade than sporadic tumors [19-22]. They are similar to sporadic cancers with respect to ER receptor status [20,23-25]. However, one study reported that BRCA2 associated tumors are more likely to be ER-positive [22]. In addition, it has been reported that BRCA2-related breast cancers are less likely to over express HER2 receptor compared to sporadic cancers $[20,25]$. Further studies are needed to investigate whether FANCD2-related breast cancers are similar to those seen $B R C A 2$ mutation carriers.

In conclusion, our study suggests that a deletion of the VHL and FANCD2 gene may be associated with coexistence of $V H L$ disease and hereditary breast cancer, but further studies are needed in this regard.

\section{Consent}

Informed consent has been obtained from the patients for publication.

\section{Competing interests}

The authors declare that they have no competing interests.

\section{Authors' contributions}

KK designed the study, collected clinical data for the study, enrolled the patients into the study group, wrote the manuscript. AJ carried out the molecular genetic studies. JG carried out the molecular genetic studies. MRK enrolled the patients into the study group. M D-S collected clinical data for the study. LS enrolled the patients into the study group. LC collected clinical data for the study. WL participated in its design and coordination. JL participated in its design and coordination. CC conceived the study, carried out the molecular genetic studies participated in writing and helped to draft the manuscript, critically revised the manuscript and approved its final version. All authors read and approved the final version of the manuscript.

\section{Author details}

${ }^{1}$ Department of Ophthalmology, Pomeranian Medical University (PUM), Szczecin, Poland. ${ }^{2}$ International Hereditary Cancer Center, Department of Genetics, Pathology PUM, Szczecin, Poland. ${ }^{3}$ Department of Medical Genetics, Poznan University of Medical Sciences, Poznan, Poland. ${ }^{4}$ Department of Neurosurgery, PUM, Szczecin, Poland. ${ }^{5}$ Department of Radiology, PUM, Szczecin, Poland.

Received: 23 January 2014 Accepted: 5 June 2014

Published: 18 June 2014

\section{References}

1. Maher ER, Iselius L, Yates JR, Littler M, Benjamin C, Harris R, Sampson J, Williams A, Ferguson-Smith MA, Morton N: von Hippel-Lindau disease: a genetic study. J Med Genet 1991, 28(7):443-447.

2. Maher ER, Yates JR, Harries R, Benjamin C, Harris R, Moore AT, FergusonSmith MA: Clinical features and natural history of von Hippel-Lindau disease. Q J Med 1990, 77(283):1151-1163.

3. Couch V, Lindor NM, Karnes PS, Michels W: von Hippel-Lindau disease. Mayo Clin Proc 2000, 75:265-272.

4. Stolle C, Glenn G, Zbar B, Humphrey JS, Choyke P, Walther M, Pack S, Hurley K, Andrey C, Klausner R, Linehan WM: Improved detection of germline mutations in the von Hippel-Lindau disease tumor suppressor gene. Hum Mutat 1998, 12:417-423.

5. Maher ER, Kaelin WG Jr: von Hippel-Lindau disease. Medicine (Baltimore) 1997, 76:381-391.

6. Cybulski C, Krzystolik K, Murgia A, Górski B, Debniak T, Jakubowska A Martella M, Kurzawski G, Prost M, Kojder I, Limon J, Nowacki P, Sagan L, Białas B, Kałuza J, Zdunek M, Omulecka A, Jaskólski D, Kostyk E, Koraszewska-Matuszewska B, Haus O, Janiszewska H, Pecold K, Starzycka M, Słomski R, Cwirko M, Sikorski A, Gliniewicz B, Cyryłowski L, Fiszer-Maliszewska L, et al: Germline mutations in the von Hippel-Lindau (VHL) gene in patients from Poland: disease presentation in patients with deletions of the entire VHL gene. J Med Genet 2002, 39(7):E38. No abstract available. 
7. Maranchie JK, Afonso A, Albert PS, Kalyandrug S, Phillips JL, Zhou S, Peterson J, Ghadimi BM, Hurley K, Riss J, Vasselli JR, Ried T, Zbar B, Choyke P, Walther MM, Klausner RD, Linehan WM: Solid renal tumor severity in von Hippel Lindau disease is related to germline deletion length and location. Hum Mutat 2004, 23:40-46.

8. Casco'n A, Escobar B, Montero-Conde C, Rodri'guez-Antona C, Ruiz-Llorente S, Osorio A, Mercadillo F, Leto'n R, Campos JM, García-Sagredo JM, Benı'tez J, Malumbres M, Robledo M: Loss of the actin regulator HSPC300 results in clear cell renal cell carcinoma protection in Von Hippel-Lindau patients. Hum Mutat 2007, 28:613-621.

9. Gerlind F, Birke B, Hoffmann MM, Markus C, Christian W, Jurgen K, Gerd S, Neumann HPH: Alu-Alu recombination underlies the vast majority of large VHL germline deletions: molecular characterization and genotypephenotype correlations in VHL patients. Hum Mutat 2009, 30(5):776-786.

10. McNeill A, Rattenberry E, Barber R, Killick P, MacDonald F, Maher ER: Genotype-phenotype correlations in VHL exon deletions. Am J Med Genet Part A 2009, 149A:2147-2151.

11. Meetei $A R$, de Winter JP, Medhurst AL, Wallisch $M$, Waisfisz $Q$, van de Vrugt $H J$, Oostra $A B$, Yan $Z$, Ling C, Bishop CE, Hoatlin ME, Joenje $H$, Wang W: A novel ubiquitin ligase is deficient in Fanconi anemia. Nat Genet 2003, 35:165-170.

12. Bagby GC Jr: Genetic basis of Fanconi anemia. Curr Opin Hematol 2003, 10:68-76.

13. Grompe M, D'Andrea A: Fanconi anemia and DNA repair. Hum Mol Genet 2001, 10:2253-2259.

14. Howlett NG, Taniguchi T, Olson S, Cox B, Waisfisz Q, De Die-Smulders C, Persky N, Grompe M, Joenje H, Pals G, Ikeda H, Fox EA, D'Andrea AD: Biallelic inactivation of BRCA2 in Fanconi anemia. Science 2002, 297(5581):606-609.

15. Houghtaling S, Timmers C, Noll M, Finegold MJ, Jones SN, Meyn MS Grompe M: Epithelial cancer in Fanconi anemia complementation group D2 (Fancd2) knockout mice. Genes Dev 2003, 17:2021-2035.

16. D'Andrea AD, Grompe M: The Fanconi anaemia/BRCA pathway. Nat Rev Cancer 2003, 3:23-34.

17. Seal S, Barfoot R, Jayatilake $H$, Smith P, Renwick A, Bascombe L, McGuffog L, Evans DG, Eccles D, Easton DF, Stratton MR, Rahman N, Breast Cancer Susceptibility Collaboration: Evaluation of Fanconi Anemia genes in familial breast cancer predisposition. Cancer Res 2003, 63:8596-8599.

18. Lewis AG, Flanagan J, Marsh A, Pupo GM, Mann G, Spurdle AB, Lindeman GJ Visvader JE, Brown MA, Chenevix-Trench G: Kathleen Cuningham Foundation Consortium for Research into Familial Breast Cancer. Mutation analysis of FANCD2, BRIP1/BACH1, LMO4 and SFN in familial breast cancer. Breast Cancer Res 2005, 7(6):R1005-R1016.

19. Vargas AC, Silva LD, Lakhani SR: The contribution of breast cancer pathology to statistical models to predict mutation risk in BRCA carriers. Fam Cancer 2010, 9:545-553.

20. Lakhani SR, Van De Vijver MJ, Jacquemier J, Anderson TJ, Osin PP, McGuffog L, Easton DF: The pathology of familial breast cancer: predictive value of immunohistochemical markers estrogen receptor, progesterone receptor, HER-2, and p53 in patients with mutations in BRCA1 and BRCA2. J Clin Oncol 2002, 20:2310-2318.

21. Phillips KA: Immunophenotypic and pathologic differences between BRCA1 and BRCA2 hereditary breast cancers. J Clin Oncol 2000, 18:107S-112S

22. Bane AL, Beck JC, Bleiweiss I, Buys SS, Catalano E, Daly MB, Giles G, Godwin AK, Hibshoosh H, Hopper JL, John EM, Layfield L, Longacre T, Miron A, Senie R, Southey MC, West DW, Whittemore AS, Wu H, Andrulis IL, O'Malley FP: BRCA2 mutation-associated breast cancers exhibit a distinguishing phenotype based on morphology and molecular profiles from tissue microarrays. Am J Surg Pathol 2007, 31:121-128.

23. Armes JE, Trute L, White D, Southey MC, Hammet F, Tesoriero A, Hutchins AM, Dite GS, McCredie MR, Giles GG, Hopper JL, Venter DJ: Distinct molecular pathogeneses of early-onset breast cancers in BRCA1 and BRCA2 mutation carriers: a population-based study. Cancer Res 1999, 59:2011-2017.

24. Palacios J, Honrado E, Osorio A, Cazorla A, Sarrió D, Barroso A, Rodríguez S, Cigudosa JC, Diez O, Alonso C, Lerma E, Dopazo J, Rivas C, Benítez J: Phenotypic characterization of BRCA1 and BRCA2 tumors based in a tissue microarray study with 37 immunohistochemical markers. Breast Cancer Res Treat 2005, 90:5-14.
25. Lakhani SR, Reis-Filho JS, Fulford L, Penault-Llorca F, van der Vijver M, Parry S, Bishop T, Benitez J, Rivas C, Bignon YJ, Chang-Claude J, Hamann U, Cornelisse CJ, Devilee P, Beckmann MW, Nestle-Krämling C, Daly PA, Haites N, Varley J, Lalloo F, Evans G, Maugard C, Meijers-Heijboer H, Klijn JG, Olah E, Gusterson BA, Pilotti S, Radice P, Scherneck S, Sobol H, et al: Prediction of BRCA1 status in patients with breast cancer using estrogen receptor and basal phenotype. Clin Cancer Res 2005, 11:5175-5180.

doi:10.1186/1897-4287-12-16

Cite this article as: Krzystolik et al:: Large deletion causing von Hippel-Lindau disease and hereditary breast cancer syndrome. Hereditary Cancer in Clinical Practice 2014 12:16.

\section{Submit your next manuscript to BioMed Central and take full advantage of:}

- Convenient online submission

- Thorough peer review

- No space constraints or color figure charges

- Immediate publication on acceptance

- Inclusion in PubMed, CAS, Scopus and Google Scholar

- Research which is freely available for redistribution

Submit your manuscript at www.biomedcentral.com/submit
C Biomed Central 